Çukurova Üniversitesi Mühendislik Mimarlık Fakültesi Dergisi, 33(2), ss. 17-32, Haziran 2018

Çukurova University Journal of the Faculty of Engineering and Architecture, 33(2), pp. 17-32, June 2018

\title{
Çamlıyayla (Mersin) Yöresindeki Magmatik Kompleksin Petrografisi ve Jeokimyası, Güney Türkiye
}

\author{
Utku BAĞCI ${ }^{* 1}$, Hayati KOÇ ${ }^{1}$, Murat CAMUZCOĞLU ${ }^{1}$, Musa ALPASLAN ${ }^{1}$ \\ ${ }^{1}$ Mersin Üniversitesi, Mühendislik Fakültesi, Jeoloji Mühendisliği Bölümü, Mersin
}

$\ddot{O} \mathbf{z}$

Geliş tarihi: $31.10 .2017 \quad$ Kabul tarihi: 29.06 .2018

Çamlıyayla (Mersin) güneyinde yer alan magmatik kompleks Mersin melanjı içerisinde blok olarak bulunmakta, granit, granodiyorit, granofir, granit porfir, diyorit ve diyabaz kayaçlarından oluşmaktadır. Granitik kayaçlar granüler, mikrogranüler porfirik mikrografik doku sunarken diyoritler ofitik, diyabaz daykları entergranüler doku sunmaktadır. Ana-iz element jeokimyası bu kayaçların subalkali karakterde olduğunu göstermektedir. Kondrite göre normalize edilmiş nadir toprak element diyagramı hafif nadir toprak elementlerince hafif bir tüketilme, negatif Eu anomalisi ve yataya yakın bir dağılım sunmaktadır. Granitik kayaçların okyanus sırtı granitlerine göre normalize edilmiş örümcek diyagramlarında iri katyonlu litofil elementler ve yüksek değerlikli katyonlar bakımından tüketilme sunarken, diyorit ve diyabaz daykların okyanus ortası sırt bazaltlarına göre normalize edilmiş örümcek diyagramları yüksek iyon yarıçaplı elementlerce zenginleşme, kalıcılığı yüksek elementlerce tüketilme sunmaktadırlar. Alterasyona karşı duraylı iz elementlere dayandırılan tektonomagmatik ortam ayırım diyagramlarında magmatik komplekse ait kayaçlar yay ile ilişkili tektonik ortamları işaret etmektedir.

Anahtar Kelimeler: Petrografi, Jeokimya, Magmatik kompleks, Mersin melanj1, Mersin

\section{The Petrography and Geochemistry of the Magmatic Complex from the Çamlıyayla (Mersin) Area, Southern Turkey}

\begin{abstract}
The magmatic complex is located in south of Çamliyayla (Mersin), as block in the Mersin melange and composed of granite, granodiorite, granophyre, granite porphyry, diorite, and diabase. Granitic rocks present granular, microgranular porphyric, micrographic textures while diorites present ophitic and diabase dikes present intergranular textures. The whole rock major and trace element geochemistry of the magmatic complex rocks indicate that they have subalkaline compositions. Chondrite-normalized rare earth elements diagram display slightly depletion in light rare earth elements and negative Eu anomalies with nearly flat patterns. Ocean ridge granites normalized spider diagram of granitic rocks show large ion litophile element and high field strength element depletion whereas mid-ocean ridge basalt normalized spider diagram of the diorite and diabase rocks exhibit large ion litophile element enrichment and high field strength element depletion. The magmatic complex rocks are plotted on arc setting based on the immobile trace element diagrams.
\end{abstract}

Keywords: Petrography, Geochemisty, Magmatic complex, Mersin melange, Mersin

*Sorumlu yazar (Corresponding author): Utku BAĞCI, bagciu@mersin.edu.tr 


\section{GíRiş}

Orta Toroslar stratigrafik özellikleri ve kapsadıkları kaya birimleri açısından birbirinden değişik havza koşullarını yansıtan kaya topluluklarını kapsamaktadır. Bu topluluklar farklı araştırmacılar tarafindan [1-9] değişik birlikler adı altında tanımlanmıştır. Ofiyolitler, ofiyolitik melanj ve bunlarla ilişkili birimler, Bozkır Birliği içerisinde yer almaktadır $[1,2]$.

İnceleme alanı, Orta Torosların doğu kesiminde Mersin'in kuzey-kuzeydoğusunda yer alan Çamlıyayla İlçesi'nin $25 \mathrm{~km}$ güneyinde Pirömerli Köyü civarında yer almakta olup, 1/25.000 ölçekli Adana N33 d3 paftası içerisinde yaklaşık $30 \mathrm{~km}^{2}$ 'lik bir alanı kapsamaktadır (Şekil 1).

Çalışma alanında yüzeyleyen, genel olarak asidik, bazik ve nötr karakterli derinlik, yarı derinlik ve yüzey kayaçlarının birbiri içerisinde düzensiz ve farklı zamanlı sokulumlardan oluşan magmatik kompleks ilk olarak Keniş [10] tarafından ofiyolitik birimler içerisinde değerlendirilmiş, Türkmen [11,12] tarafından magmatik kaya kompleksi, daha sonraki çalışmalarda ise magmatik kompleks olarak adlandırılmış ve birimin yaşı, Üst Kretase olarak önerilmiştir [12-15].

Parlak [16], Parlak ve Robertson [17], çalışma alanının yaklaşık $40 \mathrm{~km}$ batısında mostra veren Mersin melanj1 içerisinde blok olarak granitik kayaçların gözlendiğini belirterek bu kayaçları meta-granit olarak tanımlamışlardır. Metagranitlerde gözlenen muskovit minerali üzerinde $\mathrm{K}$-Ar radyometrik yaş çalışması ile granitik

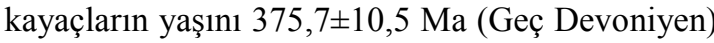
olarak tespit ederek, jeokimyasal veriler 1 şı̆̆ altında yitim ile ilgili tektonik ortamlarda oluştuklarını belirtmişlerdir [16,17].

Şimdiye kadar yapılan çalışmalarda, inceleme alanında yüzeyleyen magmatik komplekse ait kayaçların jeokimyası ile ilgili herhangi bir çalışma yapılmamıştır. Bu nedenle bu çalışmada, Çamliyayla (Mersin) yöresinde yüzeylenen magmatik komplekse ait kayaçların petrografik ve jeokimyasal özelliklerinin sunularak, oluştukları tektonik ortamın belirlenmesi amaçlanmıştır.

\section{BÖLGESEL JEOLOJİ}

Çalışma alanının temelinde, platform karbonatlarından oluşan Jura-Kretase yaşlı Demirkazık formasyonu yer almakta olup, birim bölgede Cehennemdere formasyonu olarak tanımlanmaktadır $[4,18,19]$. İnceleme alanında, Demirkazık formasyonu üzerine Mersin melanjı, bu birim üzerine de Mersin ofiyoliti tektonik olarak gelir (Şekil 2). Bu çalışmanın esas konusu olan magmatik kompleks birimleri stratigrafik olarak Mersin Melanjı içerisinde blok olarak yer almaktadır (Şekil 2). Blok olarak yer alan magmatik kompleksin dokanağı, Mersin ofiyoliti ile tektoniktir ya da çalışma alanının güney kesimlerinde Tersiyer yaşlı birimler tarafindan uyumsuzlukla örtülmektedir (Şekil 3).

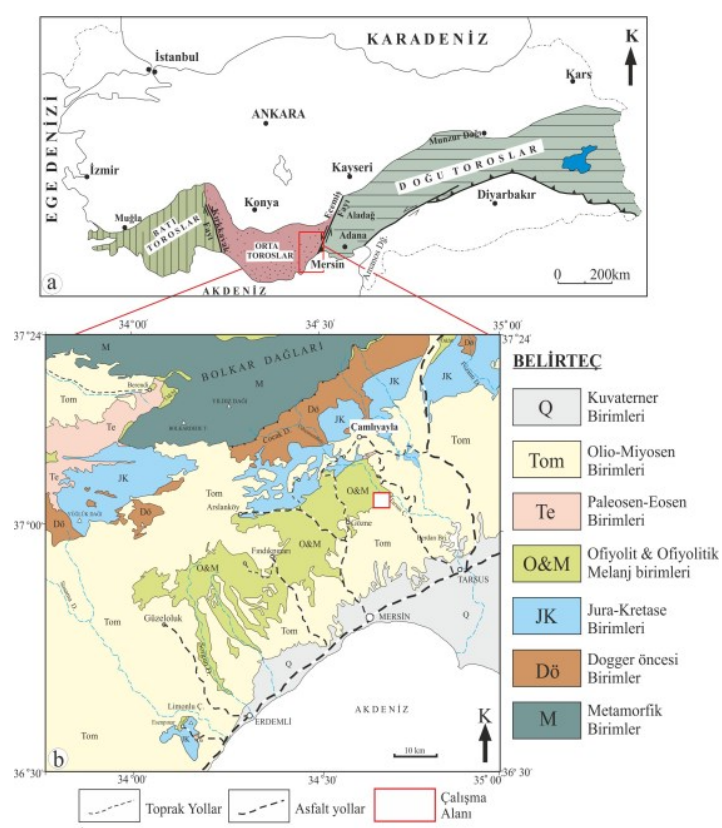

Şekil 1. a) Torosların coğrafik ayırımı [2]; b) Mersin bölgesinin basitleştirilmiş jeolojik haritası [4]'den değiştirilerek alınmıştır

Bölgede yüzeyleyen melanj birimi, ilk olarak Tepeköy Melanjı [20], sonraki çalışmalarda 
Fındıkpınarı Melanjı [21] ve son olarak Mersin ofiyolitik kompleksinin Mersin Melanj1 [16,17] olarak tanımlanmıştır. Mersin melanjı; Üst Permiyen-Üst Kretase yaşlı kireçtaşı blokları; Üst Triyas-Üst Kretase yaşlı volkanik kayaç, silisliklastikler ve pelajikler; Üst Jura-Üst Kretase yaşlı bazalt, radiyolarit, pelajik kireçtaşları; Üst Kretase yaşlı ofiyolitik kayaç blokları ile bunları bağlayan bir matriksten oluşmaktadır. Mersin melanj1, Mersin Ofiyolitinin kıta kenarına yerleşmesi esnasında oluşmuştur.

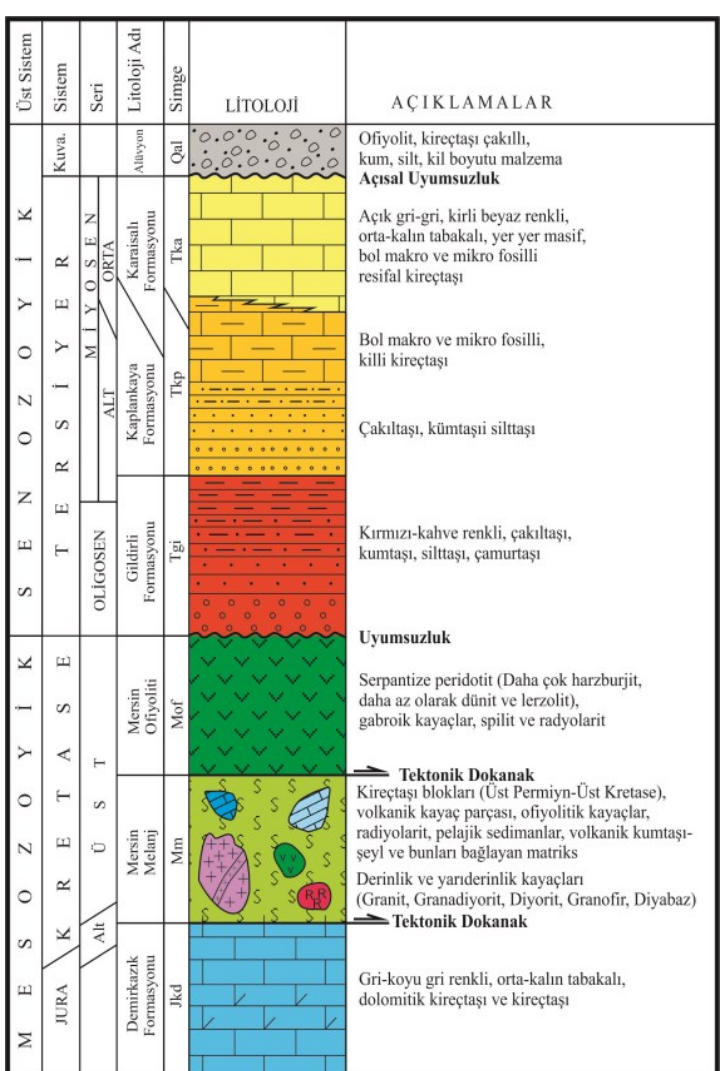

Şekil 2. Çalışma alanının genelleştirilmiş stratigrafik kesiti [13]'den değiştirilerek alınmıştır

Yaklaşık 6 km kalınlığında bir okyanus kabuğunu temsil eden Mersin ofiyoliti tabandan tavana doğru metamorfik bir dilimi, harzburjitleri, ultramafik ve mafik kümülatları, bazalt ve derin deniz sedimanlarını içermektedir [16,22]. Çalışma alanı ve yakın civarında, Mersin ofiyoliti ile Mersin melanjının dokanağı tektoniktir (Şekil 2). Ayrıca birim, inceleme alanında Mersin melanjına ait magmatik kompleks ile tektonik dokanak sunmakta ve Tersiyer yaşlı birimler tarafindan uyumsuzlukla üzerlenmektedir (Şekil 3). Bütün bu birimler çalışma alanının dışında kırıntılılarla başlayıp, karbonatlı kayaçlarla devam eden Geç Paleosen-Eosen yaşlı birimler tarafindan uyumsuz olarak üzerlenir [23,24]. Çalıșma alanında ise Adana havzasında yüzeyleyen geniş yayılım gösteren, kırıntılılarla başlayıp, karbonatlı kayaçlarla devam eden Oligosen-Miyosen yaşlı birimler tarafindan uyumsuzlukla örtülürler [25] (Şekil 2 ve 3). Bu Tersiyer yaşli birimlerin tabanında, karasal, gel-git ile sı̆̆ deniz nitelikli Oligosen-Alt Miyosen yaşlı Gildirli formasyonu yer almaktadır (Şekil 2). Birim, karasal nitelikli çakıltaşı, kumtaşı, silttaşı ve kiltaşları ile temsil edilmektedir. Gildirli formasyonu üzerine uyumlu olarak Alt-Orta Miyosen yaşlı kumlu-siltli kireçtaşı, çakıllı kumtaşı ve marnlardan oluşan Kaplankaya formasyonu gelir. Tabanda kırıntılarla başlayıp yukarı doğru kırıntı oranı azalan, karbonat oranı artan bir istiften oluşan birimin stratigrafik konumu ve fosil içeriğine göre sı ̆ deniz-plaj ortamı ve resif gerisi lagün ortamında çökelmiş olduğunu göstermektedir. $\mathrm{Bu}$ birimle yanal ve düşey geçiş sunan Alt-Orta Miyosen yaşlı Karaisalı formasyonu ise bol fosilli, resifal özellikli kireçtaşları ile temsil edilir. Birimin litolojik özellikleri ve fosil içeriği, sı ̆ denizel ve resifal bir ortamda çökeldiğini işaret etmektedir.

\section{MATERYAL VE METOT}

Çalıșmanın konusunu oluşturan magmatik kaya kompleksine ait kayaçlar arazide detaylı bir şekilde incelenmiş, farklı litolojideki kayaçlar birbirinden ayırt edilmiştir. Ana kütle ve dayk şeklinde gözlenen bu kayaçların birbirleri ile dokanak ilişkileri belirlenmiş, farklı litolojideki değişik seviyelerden, kayaçların petrografik özelliklerinin belirlenmesi için toplam 40 adet örnek alımı gerçekleştirilmiştir. Detaylı petrografik tanımlama sonrası jeokimyasal analizler için belirlenen 18 adet örnek üzerinde ana, iz ve nadir toprak element (REE) analizleri Acme Analitik laboratuvarlarında (Kanada) yaptırılmıştır. Ana elementler ile bazı iz 
element analizleri $0,2 \mathrm{~g}$ örneğe lityum metaborat/tetraborat katılmasiyla nitrik asit ile çözüldükten sonra ICP-emisyon spektrometresi (ICP-AES) ile ölçümü yapılmıştır. Ateşte kayıp değerleri (LOI) örneklerin $1000{ }^{\circ} \mathrm{C}$ 'de 1 sitıldıktan sonra, aradaki ağırlık farkı alınarak hesaplanmıștır. Nadir toprak elementleri ile diğer iz elementler (refrakter elementler) aynı yöntem ile ICP-kütle spektrometresi (ICP-MS) ile ölçülmüştür.

Dedeksiyon limitleri; ana oksitler için $\% 0,002-0,01$, iz elementler için 0,1-8 ppm, nadir toprak elementleri için $0,01-0,1$ ppm arasında değişmektedir.

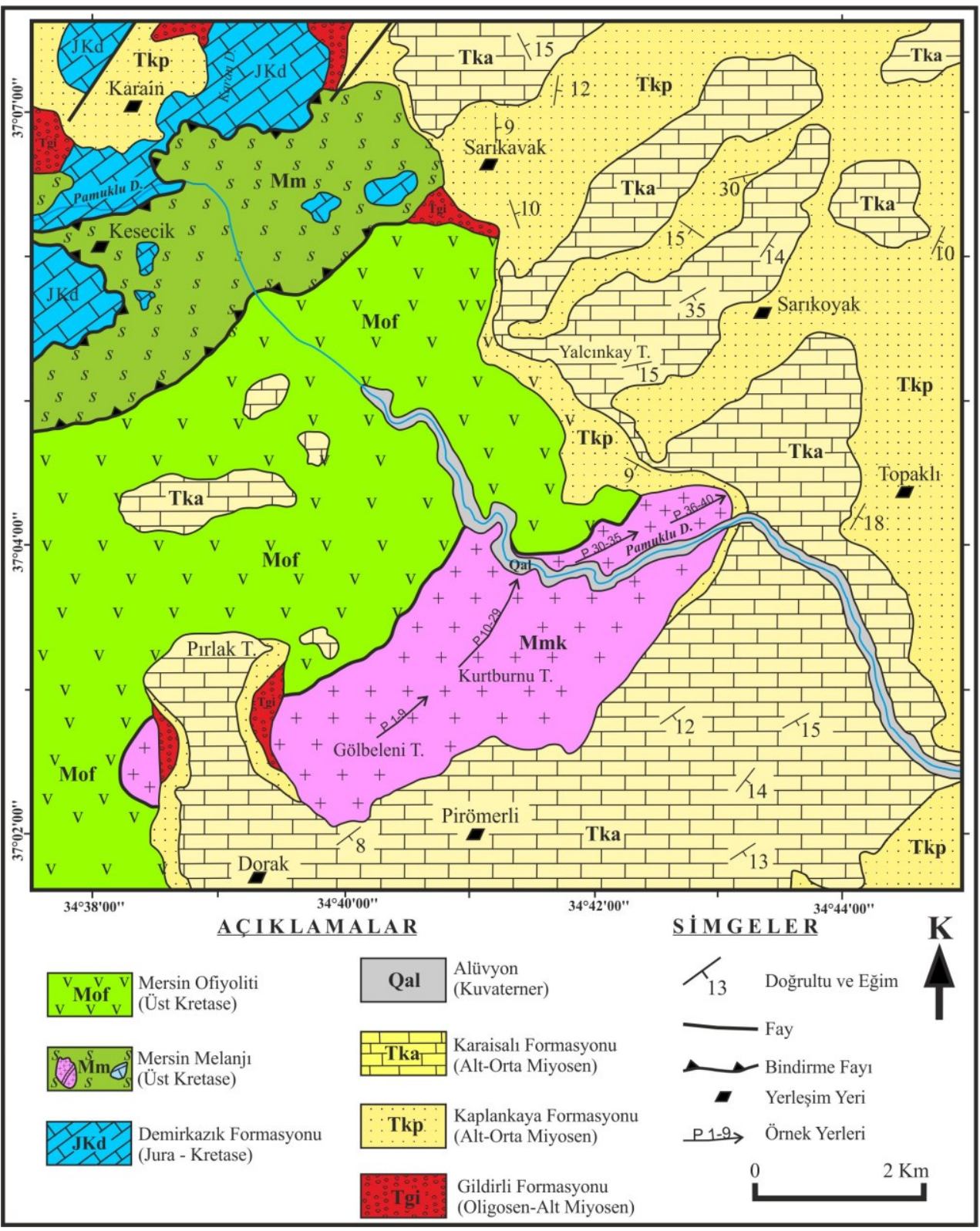

Şekil 3. Pirömerli (Çamlıyayla-Mersin) civarının jeoloji haritası [13]'den değiştirilerek alınmıştır 


\section{PETROGRAFi}

Çalışma alanında Pamuklu vadisinde gözlenen magmatik kaya kompleksinin ana kütlesini granitoyidik kayaçlar oluşturmaktadır. Tektonizma etkisi sonucu ayrışmanın özellikle arenalaşmanın gözlendiği granitik kayaçlar, açık renkli, sert, sağlam, yer yer çok çatlaklı bir yapıya sahiptirler (Şekil 4a-d). Düzensiz bir şekilde gözlenen granitik kayaçlar diyorit ve diyabaz dayklar tarafından kesilmektedir (Şekil 4e, f). Detaylı petrografik çalışmanın sonucunda magmatik kaya kompleksinin granit, granodiyorit, granofir, granit porfir, diyorit ve diyabaz gibi derinlik ve yarı derinlik kayaçlarından oluştuğu belirlenmiştir (Çizelge 1).

\subsection{Granit}

Holokristalin hipidiyomorf granüler dokunun gözlendiği kayaç içerisinde başlıca plajiyoklaz, kuvars ve ortoklaz mineralleri gözlenmektedir. Plajiyoklazlar, genellikle yarıözşekilli olup, yassıçubuksu ve prizmatik formlarda, polisentetik ikizlenme ile zonlanma sunmaktadırlar. Kuvarslar, özşekilsiz olup, dalgalı yanıp sönme göstermektedir. Ortaklazlar yaygın olarak killeşmiştir. Amfibollerden itibaren gelişmiş düzensiz şekilli ikincil opak mineraller ile manyetit olabilecekleri tahmin edilen bir kısmı düzgün kenar ve köşelere sahip birincil opaklar kayaç içerisinde tali miktarlarda gözlenmektedir (Şekil 5a).

\subsection{Granodiyorit}

Holokristalin hipidiyomorf granüler dokunun gözlendiği kayaç içerisinde başlica plajiyoklaz, kuvars, ortoklaz, amfibol ve opak mineralleri gözlenmektedir. Plajiyoklazlar küçük çubuğumsu formlarda, polisentetik ikizlenme sunmakta, kaolenleşme ve serisitleşme göstermektedirler. Grinin tonlarında girişim renkleri sunan kuvarslar genellikle özşekilsiz kristaller halinde izlenmekte ve dalgalı yanıp sönme göstermektedirler. Ortoklazlar ise oldukça killeşmiş özşekilsiz kristaller halinde kayaç içerisinde bulunmaktadır.
Yeşilin tonlarında pleokroyizma gösteren hornblendler yer yer kloritleşme ve opaklaşma göstermektedirler. Tali miktarlarda birincil ve ikincil opak mineralleri bulunmaktadır (Şekil 5b).

\subsection{Granofir}

Mikrografik dokunun gözlendiği kayaç içerisinde, genellikle özşekilsiz mikrogranüler ve fenokristal halinde bir k1smı ise alkali feldispat mineralleri ile eşzamanlı büyüme gösteren kuvars mineralleri maruz kaldıkları basınç sonucunda dalgalı sönme gösterirler. Alkali feldispatlarda killeşme ileri derecelerde izlenmektedir. Killeşme ve serisitleşmenin fazla olduğu plajiyoklaz mineralleri ise alterasyondan dolayı güçlükle tanınmakta, yer yer zonlanma göstermektedirler. Kayaç içerisinde ayrıca tali miktarlarda birincil ve ferromagnezyen minerallerden itibaren gelişmiş opak mineralleri gözlenmektedir (Şekil 5c).

\subsection{Granit Porfir}

Mikrogranüler porfirik dokunun gözlendiği kayaç içinde, hem iri fenokristaller halinde hem de mikrogranüler taneler halinde özşekilsiz kristaller olarak izlenen kuvarslar, maruz kalmış oldukları basınç nedeni ile dalgalı yanıp sönme gösterirler. Ortoklaz, kuvars ve plajiyoklaz minerallerinden oluşmuş hamur içerisinde bu minerallerin fenokristalleri düzensiz olarak gözlenmektedir. Kuvarsların bir kısmı oluşturduğu mikrogranüler hamur tarafindan yenilerek korozyona uğratılmış (korrode) şekillerde izlenmektedir (Şekil 5d). Mafik mineral olarak hornblendler gözlenmekte, tali miktarlarda ise opak minerali bulunmaktadır.

\subsection{Diyorit}

Subofitik dokunun gözlendiği kayaç içerisinde felsik minerali temsil eden plajiyoklazlar yaklaşık \%50-60 oranında yer almaktadırlar. Prizmatik şekillerde izlenen, yer yer polisentetik ikizleri belirgin olan ve oldukça büyük bir kısmı zonlanma gösteren plajiyoklazların büyük bir kısmında killeşme ve serisitleşme gözlenmektedir. Hornblend mineralleri ise kloritleşme ve opaklaşma göstermektedirler (Şekil 5e). 


\subsection{Diyabaz}

Entergranüler dokunun gözlendiği kayaç içerisinde büyük çoğunluğu oluşturan plajiyoklazlar ince uzun prizmatik, yarı özşekilli mikrolitler şeklinde albitleşmiş olarak gözlenmektedir. Plajiyoklaz mikrolitleri arasında klinopiroksenlerin çoğunluğu uralitleşme göstererek amfibol minerallerine dönüşmüşlerdir. İkincil olarak klorit, epidot mineralleri gözlenen kayaç içinde köşeli birincil opak mineralleri ile ferromagnezyen minerallerden itibaren gelişmiş olan düzensiz ikincil opak mineraller de bulunmaktadır (Şekil 5f).
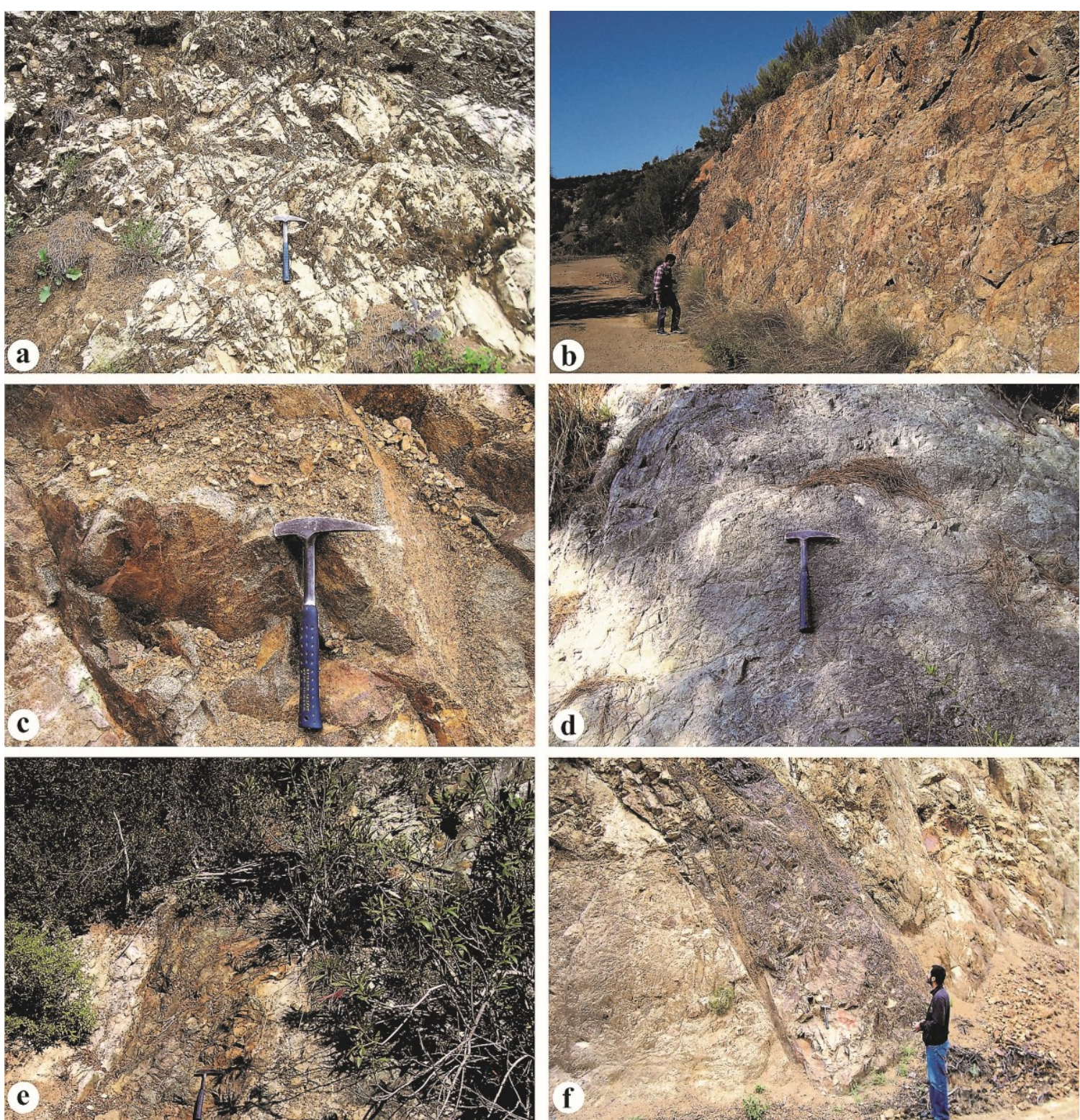

Şekil 4. Magmatik komplekse ait kayaçların arazi görüntüleri. Granitlerin genel görünümleri (a, b, c), diyoritlerin genel görünümü $(\mathrm{d})$, diyabaz daykları $(\mathrm{e}, \mathrm{f})$ 

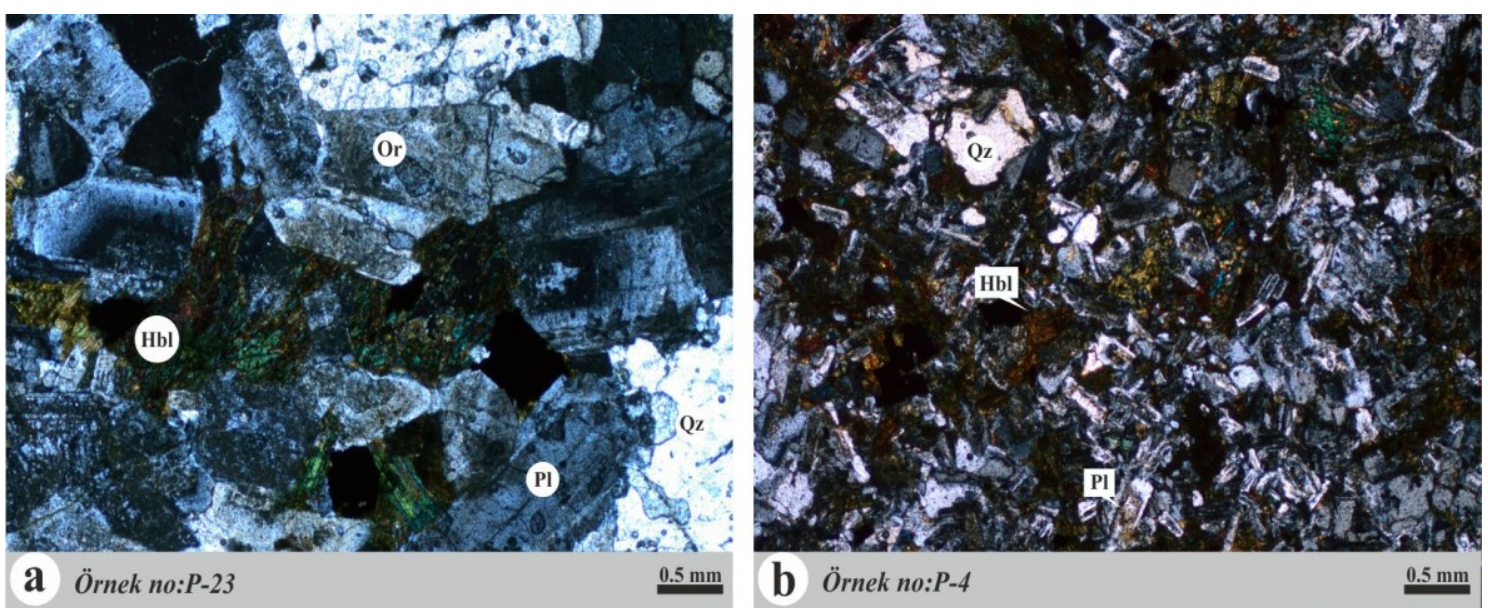

a Örnek no:P-23
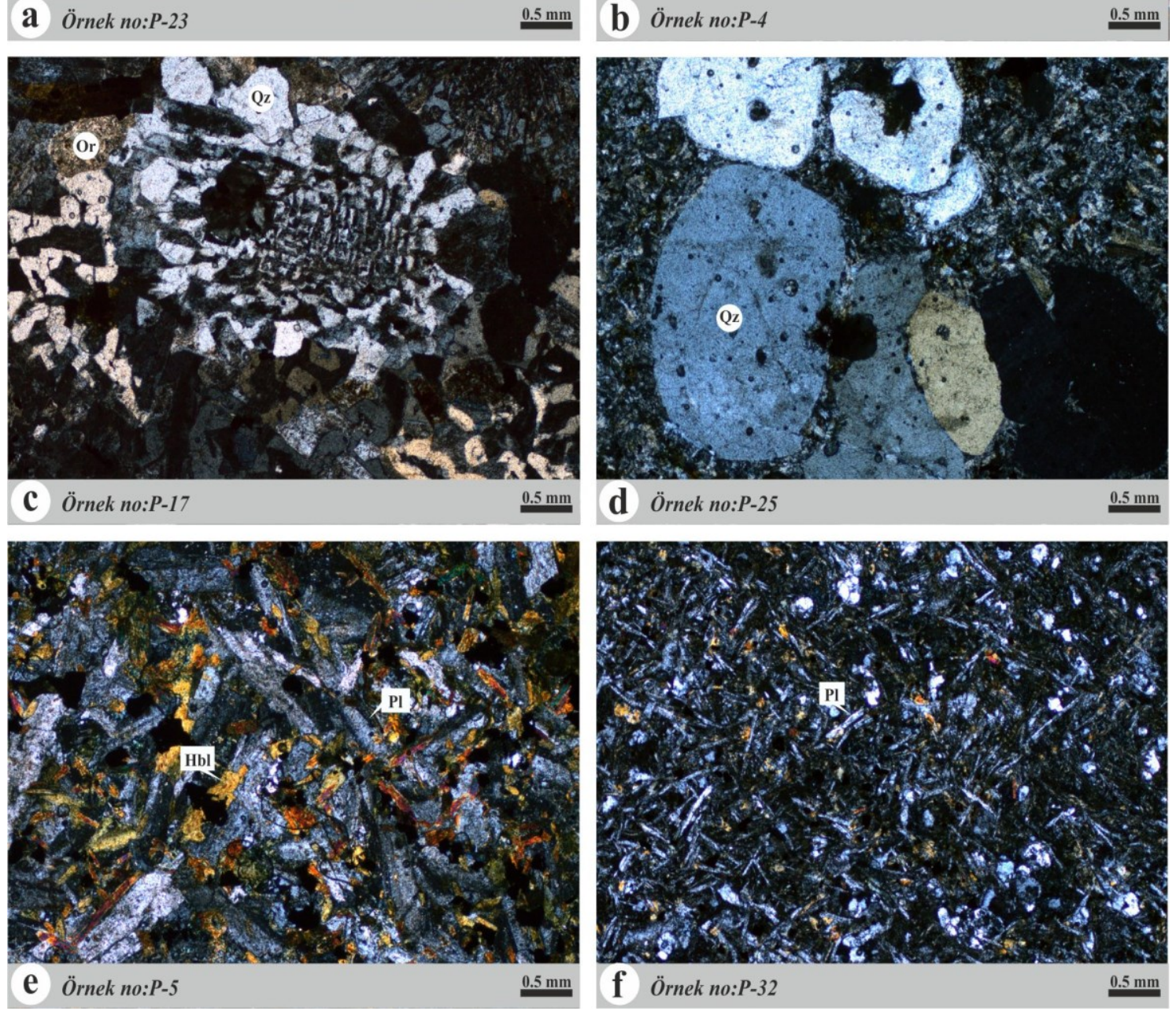

Şekil 5. Magmatik komplekse ait kayaçların mikroskobik görüntüleri. Granit (a), Granodiyorit (b), Granofir (c), Granit porfir (d), Diyorit (e), Diyabaz (f). Qz: Kuvars, Or: Ortoklaz, Pl: Plajiyoklaz, Hbl: Hornblend; Çift Nikol; (Mineral kısaltmaları [26]'den alınmıştır) 


\section{JEOKIMYYA}

Magmatik kayaç kompleksine ait kayaçların ana, iz ve nadir toprak element analiz sonuçları Çizelge 2'de sunulmuştur. Ateşte kayıp değerleri granitoyidler için \%0,8-3,2, diyorit ve diyabaz daykları için \%1,9-4,1 arasında değişmektedir. Ateşte kayıp değerleri, petrografik tanımlamalarda klorit, epidot, opak ve kil minerallerinin bulunmasından da anlaşılacağı üzere, önemli ölçüde alterasyonun varlığına işaret etmektedir.
Granitoyid kayaçları yüksek $\mathrm{SiO}_{2}(\% 61,37-75,89)$ ve düşük $\mathrm{TiO}_{2}(\% 0,18-1), \mathrm{Al}_{2} \mathrm{O}_{3}(\% 11,24-14,41)$, $\mathrm{Fe}_{2} \mathrm{O}_{3} \quad(\% 3,42-9,90), \quad \mathrm{MgO}(\% 0,21-1,98), \quad \mathrm{CaO}$ $(\% 0,67-3,97)$, Co $(1,2-9,9$ ppm), Ga (12,3$16,3 \mathrm{ppm})$, Sc (7-26 ppm) içeriklerine sahipken, diyoritler ve diyabaz daykları düşük $\mathrm{SiO}_{2}(54,38$ 57,62) ve yüksek $\mathrm{TiO}_{2} \quad(\% 0,86-1,41), \quad \mathrm{Al}_{2} \mathrm{O}_{3}$ $(\% 13,82-15,10), \quad \mathrm{Fe}_{2} \mathrm{O}_{3} \quad(\% 10,08-12,35), \quad \mathrm{MgO}$ $(\% 3,18-4,98) \quad \mathrm{CaO}(\% 1,23-7,11)$, Co $(20,3-$ 25,8 ppm), Ga(15,1-17,7 ppm), Sc (27-33 ppm) içeriklerine sahiptirler (Çizelge 1).

Çizelge 1. Magmatik kaya kompleksi kayaçların petrografik özellikleri (\% miktarı)

\begin{tabular}{|c|c|c|c|c|c|c|}
\hline $\begin{array}{c}\text { Kayaç Grubu } \\
\text { Doku } \\
\text { Mineraller }\end{array}$ & $\begin{array}{c}\text { Granit } \\
\text { Granüler }\end{array}$ & $\begin{array}{l}\text { Granodiyorit } \\
\text { Granüler }\end{array}$ & $\begin{array}{c}\text { Granofîr } \\
\text { Mikro Grafik }\end{array}$ & $\begin{array}{c}\text { Granit Porfir } \\
\text { Mikrogranüler Porfirik }\end{array}$ & $\begin{array}{l}\text { Diyorit } \\
\text { Ofitik }\end{array}$ & $\begin{array}{c}\text { Diyabaz } \\
\text { Entergranüler }\end{array}$ \\
\hline Kuvars & $30-35$ & $25-30$ & $40-50$ & $30-40$ & 5 & \\
\hline Ortoklaz & $15-20$ & $5-10$ & $20-30$ & $15-20$ & & \\
\hline Plajiyoklaz & $30-40$ & $40-45$ & $25-30$ & $30-40$ & $50-60$ & $30-40$ \\
\hline Horblend & $15-20$ & $15-20$ & $10-20$ & $15-20$ & $30-35$ & $30-35$ \\
\hline Klinopiroksen & & & & & & 5 \\
\hline Opak & $5-10$ & 10 & 5 & 5 & $5-10$ & $10-20$ \\
\hline Klorit & & 5 & & & 5 & $10-15$ \\
\hline Epidot & & & & & 5 & 5 \\
\hline
\end{tabular}

Magmatik komplekse ait kayaçların toplam alkali $\left(\mathrm{Na}_{2} \mathrm{O}+\mathrm{K}_{2} \mathrm{O}\right)$ içeriklerinin $\mathrm{SiO}_{2}$ içeriğe göre değişimi [27] incelendiğinde örneklerin subalkali karakterde olduğu (Şekil 6a) gözlenmektedir.

Hareketsiz iz elementlere göre çizilen volkanik kökenli kayaçlar için kullanılan $\mathrm{Nb} / \mathrm{Y}-\mathrm{Zr} / \mathrm{Ti}$ diyagramı [28] aynı bileşimdeki derinlik kayaçları için kullanılarak, magmatik komplekse ait granitik kayaçların andezit bazaltik andezit alanı ile riyolit ve dasit alanına düştükleri, diyorit ve diyabaz daykların bazalt alanında yer aldığı ve subalkali karakter sundukları görülmektedir (Şekil 6b).

Ana ve iz element içeriklerinin $\mathrm{SiO}_{2}$ içeriğine karşı değişimi incelendiğinde, $\mathrm{TiO}_{2}, \mathrm{Al}_{2} \mathrm{O}_{3}, \quad \mathrm{Fe}_{2} \mathrm{O}_{3}$, $\mathrm{MgO}, \mathrm{CaO}, \mathrm{Co}, \mathrm{Ga}$ ve Sc içeriklerinin $\operatorname{artan} \mathrm{SiO}_{2}$ içeriğine karşı azalması, aralarında negatif bir ilişki olması (Şekil 7a-i), feldispat ve hornblend minerallerinin kristallenmesini işaret etmektedir.

Magmatik kaya kompleksine ait kayaçların kondrite göre normalize edilmiş nadir toprak element (REE) diyagramında (Şekil 8a,b) örnekler yatay veya yataya yakın bir dağılım göstermekte $\left[(\mathrm{La} / \mathrm{Yb})_{\mathrm{N}}=0,44-0,66\right]$, hafif nadir toprak elementler (LREE) bakımından zayıf bir tüketilme ile feldispat fraksiyonlanmasını işaret eden negatif $\mathrm{Eu}$ anomalisi (granitik kayaçlar için $\mathrm{Eu} / \mathrm{Eu}^{*}=$ 0,62-1; diyorit ve diyabazlar için $\mathrm{Eu} / \mathrm{Eu}^{*}=0,74$ $0,94)$ sunmaktadirlar.

Aynı diyagramda Parlak ve Roberson [17] çalışmasındaki metagranitlerin REE desenleri hafif nadir toprak elementler bakımında oldukça fazla zenginleşme göstermektedir. 
Çizelge 2. Magmatik Kaya kompleksi kayaçlarına ait ana (\% ağırlık)-iz element (ppm) değerleri

\begin{tabular}{|c|c|c|c|c|c|c|c|c|c|c|c|c|c|c|c|c|c|c|}
\hline \multirow[b]{2}{*}{ Örnek } & \multicolumn{3}{|c|}{ Granit } & \multicolumn{4}{|c|}{ Granofir } & \multicolumn{3}{|c|}{ Granit Porfir } & \multicolumn{2}{|c|}{ Granodiyorit } & \multicolumn{3}{|c|}{ Diyorit } & \multicolumn{3}{|c|}{ Diyabaz } \\
\hline & P-29 & P-22 & P-23 & P-15 & P-17 & P-12 & P-33 & P-25 & \begin{tabular}{|l|} 
P-26 \\
\end{tabular} & P-28 & P-4 & P-16 & P-1 & P-5 & P-6 & P-10 & P-18 & P-32 \\
\hline $\mathrm{SiO}_{2}$ & 75,27 & 73,19 & 73,5 & 75,85 & 75,89 & 74,32 & 75,31 & 74,21 & 72,43 & 75,46 & 61,37 & 64,72 & 56,21 & 55,94 & 55,26 & 54,38 & 57,62 & \begin{tabular}{|l|}
54,39 \\
\end{tabular} \\
\hline $\mathrm{TiO}_{2}$ & 0,23 & 0,32 & 0,32 & 0,21 & 0,22 & 0,21 & 0,18 & 0,3 & 0,34 & 0,2 & 1 & 0,64 & 1,34 & 1,38 & 1,41 & 1,32 & 0,86 & 1,29 \\
\hline $\mathbf{A I}_{2} \mathbf{O}_{3}$ & 12,04 & 12,37 & 12,55 & 11,83 & 11,77 & 12,01 & 11,24 & 11,73 & 12,79 & 11,83 & 14,41 & 13,61 & 13,82 & 13,94 & 14,45 & 14,89 & 15,1 & 14,43 \\
\hline $\mathrm{tFe}_{2} \mathrm{O}_{3}$ & 3,94 & 4,39 & 4,56 & 3,75 & 3,96 & 3,42 & 4,04 & 3,97 & 4,65 & 4,04 & \begin{tabular}{|l|}
9,9 \\
\end{tabular} & 8,72 & 11,47 & 12,16 & 12,35 & 11,33 & 10,08 & 11,24 \\
\hline MnO & 0,04 & 0,05 & 0,04 & 0,03 & 0,05 & 0,03 & 0,08 & 0,06 & 0,07 & 0,04 & 0,16 & 0,1 & 0,1 & 0,15 & 0,17 & 0,15 & 0,13 & 0,22 \\
\hline MgO & 0,21 & 0,62 & 0,57 & 0,26 & 0,39 & 0,38 & 0,81 & 0,51 & 0,96 & 0,4 & 1,98 & 1,56 & 3,36 & 3,18 & 3,5 & 4,18 & 4,57 & 4,98 \\
\hline $\mathrm{CaO}$ & 2,5 & 2,38 & 2,57 & 1,29 & 1,45 & 2,56 & 0,67 & 1,21 & 0,98 & 1,39 & 3,97 & 2,57 & 5,25 & 4,38 & 4,58 & 7,11 & 1,23 & 4,9 \\
\hline $\mathrm{Na}_{2} \mathrm{O}$ & 4,65 & 4,68 & 4,52 & 5,6 & 4,95 & 4,17 & 4,46 & 5,49 & 6,14 & 5,57 & 4,86 & 5,46 & 4,61 & 5,29 & 4,78 & 4,33 & 5,61 & 3,94 \\
\hline $\mathrm{K}_{2} \mathrm{O}$ & 0,29 & 0,36 & 0,32 & 0,16 & 0,37 & 0,24 & 1,59 & 0,03 & 0,04 & 0,04 & 0,34 & 0,32 & 0,38 & 0,3 & 0,36 & 0,16 & 0,14 & 0,24 \\
\hline $\mathbf{P}_{2} \mathbf{O}_{5}$ & 0,04 & 0,07 & 0,07 & 0,03 & 0,04 & 0,05 & 0,03 & 0,08 & 0,06 & 0,04 & 0,14 & 0,29 & 0,13 & 0,12 & 0,12 & 0,1 & 0,09 & 0,11 \\
\hline $\mathrm{Cr}_{2} \mathrm{O}_{3}$ & $<0,002$ & $<0,002$ & $<0,002$ & $<0,002$ & $<0,002$ & $<0,002$ & $<0,002$ & $<0,002$ & $<0,002$ & $<0,002$ & $<0,002$ & $<0,002$ & $<0,002$ & \begin{tabular}{|l|}
0,002 \\
\end{tabular} & $<0,002$ & $<0,002$ & $<<0,002$ & \begin{tabular}{|l|}
$<002$ \\
\end{tabular} \\
\hline LOI & 0,8 & 1,6 & 1 & 1 & 0,9 & 2,6 & 1,6 & 2,4 & 1,6 & 1 & 1,8 & 2 & 3,2 & 3,1 & 2,9 & 1,9 & 4,4 & \begin{tabular}{|l|}
4,1 \\
\end{tabular} \\
\hline Toplam & 100 & 100,04 & 100,04 & 100,01 & 100,01 & 100,04 & 100,02 & 99,98 & 100 & 100,02 & 99,96 & 100 & 99,91 & 99,91 & 99,89 & 99,87 & 99,85 & 99,82 \\
\hline $\mathrm{Ba}$ & 89 & 107 & \begin{tabular}{|l|}
101 \\
\end{tabular} & 79 & \begin{tabular}{|l|}
90 \\
\end{tabular} & 52 & 72 & 10 & 11 & 13 & \begin{tabular}{|l|}
91 \\
\end{tabular} & 88 & 25 & 27 & 74 & 18 & 19 & 57 \\
\hline $\mathbf{R b}$ & 2,2 & & & 1,1 & 2,1 & & & 0,3 & 0,2 & 0,2 & 1,9 & & 1,4 & 1,2 & 1,5 & 0,8 & 1 & 1,2 \\
\hline $\mathbf{S r}$ & 88,5 & 91 & 89 & 67 & 64,5 & 102 & 51 & 45,6 & 39,6 & 59,8 & 92,1 & 84 & 105,9 & 93,9 & 136,8 & 99,2 & 75,6 & 117,7 \\
\hline $\mathbf{Y}$ & 31,9 & 36 & 33 & 40,6 & 33,8 & 11 & 42 & 38,5 & 28,3 & 38,2 & 38 & 39 & 38,7 & 37,4 & 36,7 & 30,6 & 24,7 & 31,7 \\
\hline $\mathbf{Z r}$ & 77,1 & 68 & 62 & 78,2 & 72,9 & 55 & 85 & 72 & 63,5 & 78,9 & 48 & 80 & 82,7 & 78,6 & 83,6 & 62,9 & 42 & 75,5 \\
\hline $\mathbf{N b}$ & 1,7 & $<5$ & $<5$ & 2,2 & 2,6 & $<5$ & $<5$ & 2,2 & 1,6 & 2,3 & 1,9 & $<5$ & 1,3 & 1,3 & 1,3 & 1 & 1,5 & 1,2 \\
\hline Th & 0,5 & & & 0,6 & 0,4 & & & 0,7 & 0,4 & 0,5 & 0,4 & & 0,2 & $<0,2$ & $<0,2$ & $<0,2$ & $<0,2$ & 0,2 \\
\hline Pb & 0,4 & & & 0,5 & 0,7 & & & 0,9 & 0,6 & 0,5 & 0,5 & & 0,6 & 0,5 & 0,3 & 0,2 & 0,8 & 0,5 \\
\hline Ga & 13,4 & & & 13,5 & 13,4 & & & 12,6 & 12,5 & 12,3 & 16,3 & & 15,7 & 15,1 & 17,7 & 16,5 & 15,9 & 16 \\
\hline $\mathbf{Z n}$ & 8 & & & 9 & 23 & & & 59 & 36 & 16 & 12 & & 8 & 8 & 8 & 6 & 59 & 240 \\
\hline $\mathrm{Cu}$ & 15,2 & & & 3,3 & 4 & & & 7,4 & 23,5 & 2,4 & 1,9 & & 1,1 & 1,8 & 2,3 & 5,6 & 43,4 & 26,7 \\
\hline $\mathrm{Ni}$ & 1,7 & & & 1,5 & 0,8 & & & 0,5 & 1,4 & 44,4 & 0,4 & & 1,1 & 0,6 & 0,8 & 2 & 7,9 & 6,2 \\
\hline $\mathrm{V}$ & $<8$ & & & $<8$ & $<8$ & & & 16 & 33 & 10 & 23 & & 189 & 223 & 235 & 355 & 267 & 314 \\
\hline Hf & 2,9 & & & 3 & 2,9 & & & 2,4 & 2,2 & 3 & 1,7 & & 2,7 & 2,5 & 2,8 & 1,9 & 1,2 & 2,6 \\
\hline \begin{tabular}{|l|} 
Cs \\
\end{tabular} & $<0,1$ & & & $<0,1$ & $<0,1$ & & & $<0,1$ & $<0,1$ & $<0,1$ & $<0,1$ & & $<0,1$ & $<0,1$ & $<0,1$ & $<0,1$ & $<0,1$ & $<0,1$ \\
\hline Sc & 14 & 13 & 13 & 13 & 11 & 7 & 13 & 11 & 14 & 12 & 26 & 22 & 29 & 29 & 29 & 33 & 27 & 30 \\
\hline Ta & $<0,1$ & & & 0,1 & 0,1 & & & 0,2 & $<0,1$ & 0,1 & 0,1 & & $<0,1$ & $<0,1$ & 0,1 & $<0,1$ & 0,1 & $<0,1$ \\
\hline Co & 2,2 & & & 1,6 & 1,2 & & & 3,4 & 5,9 & 3,4 & 9,9 & & 21,6 & 20,3 & 23,8 & 25,8 & 24,6 & 25,6 \\
\hline $\mathbf{U}$ & 0,3 & & & 0,2 & 0,3 & & & 0,3 & 0,2 & 0,3 & 0,2 & & 0,1 & $<0,1$ & 0,1 & $<0,1$ & 0,1 & 0,1 \\
\hline Sn & 2 & & & $<1$ & $<1$ & & & $<1$ & $<1$ & $<1$ & $<1$ & & 1 & $\begin{array}{l}<1 \\
\end{array}$ & $<1$ & $<1$ & $<1$ & 1 \\
\hline Mo & 0,7 & & & 0,9 & 0,8 & & & 0,3 & 0,5 & 0,4 & 0,5 & & 0,4 & 0,6 & 0,3 & 0,3 & 0,4 & 0,3 \\
\hline $\mathbf{A u}$ & $<0,5$ & & & 0,8 & 0,8 & & & 0,6 & $<0,5$ & 0,8 & $<0,5$ & & $<0,5$ & 1 & $<0,5$ & 1,3 & 0,7 & 0,6 \\
\hline La & 2,8 & & & 3,5 & 2,8 & & & 3,4 & 2,6 & 3,1 & 2,9 & & 2,5 & 2,7 & 2,7 & 2,1 & 2 & 2,4 \\
\hline $\mathrm{Ce}$ & 6,1 & & & 9,6 & 7,6 & & & 7,2 & 6,8 & 8,5 & 8,4 & & 8,6 & 8,6 & 9,1 & 6,8 & 5,3 & 7,8 \\
\hline $\mathrm{Pr}$ & 0,97 & & & 1,61 & 1,24 & & & 1,33 & 1,16 & 1,44 & 1,47 & & 1,55 & 1,6 & 1,63 & 1,23 & 0,93 & 1,36 \\
\hline Nd & 5,7 & & & 9,8 & 7,5 & & & 7,5 & 6,4 & 8,4 & 8,8 & & 9,7 & 9,7 & 9,1 & 7,7 & 6,2 & 7,8 \\
\hline Sm & 2,1 & & & 3,3 & 2,65 & & & 2,62 & 2,3 & 2,87 & 3,21 & & 3,37 & 3,28 & 3,41 & 2,7 & 2,24 & 2,87 \\
\hline Eu & 0,87 & & & 0,86 & 0,91 & & & 0,97 & 0,59 & 0,73 & 0,95 & & 1,25 & 1,17 & 1,27 & 0,98 & 0,81 & 0,99 \\
\hline Gd & 3,35 & & & 4,96 & 3,99 & & & 4,22 & 3,37 & 4,51 & 4,88 & & 5 & 4,94 & 5 & 4,02 & 3,07 & 4,24 \\
\hline Tb & 0,68 & & & 0,99 & 0,82 & & & 0,87 & 0,66 & 0,9 & 0,94 & & 1 & 0,95 & 0,94 & 0,78 & 0,62 & 0,81 \\
\hline Dy & 4,7 & & & 6,32 & 5,25 & & & 5,63 & 4,24 & 5,61 & 6,05 & & 6,24 & 5,85 & 6,01 & 4,84 & 3,88 & 5,02 \\
\hline Ho & 1,1 & & & 1,46 & 1,24 & & & 1,26 & 1 & 1,36 & 1,4 & & 1,4 & 1,37 & 1,37 & 1,11 & 0,87 & 1,15 \\
\hline Er & 3,46 & & & 4,44 & 3,75 & & & 3,94 & 3,07 & 4,05 & 4,13 & & 4,12 & 3,92 & 3,92 & 3,33 & 2,56 & 3,42 \\
\hline Tm & 0,56 & & & 0,7 & 0,59 & & & 0,63 & 0,5 & 0,63 & 0,66 & & 0,64 & 0,6 & 0,61 & 0,52 & 0,41 & 0,53 \\
\hline $\mathbf{Y b}$ & 3,67 & & & 4,62 & 3,84 & & & 4,07 & 3,29 & 4,25 & 4,18 & & 4,04 & 3,86 & 3,93 & 3,25 & 2,55 & 3,42 \\
\hline $\mathbf{L u}$ & 0,58 & & & 0,71 & 0,61 & & & 0,67 & 0,5 & 0,67 & 0,63 & & 0,6 & 0,59 & 0,59 & 0,49 & 0,4 & 0,53 \\
\hline$(\mathbf{L a} / \mathbf{Y b})_{\mathrm{N}}$ & 0,55 & & & 0,60 & 0,52 & & & 0,60 & 0,57 & 0,52 & 0,50 & & 0,44 & 0,50 & 0,53 & 0,66 & 0,56 & 0,50 \\
\hline $\mathbf{E u} / \mathbf{E u}{ }^{*}$ & 1,00 & & & 0,62 & 0,85 & & & 0,89 & 0,65 & 0,62 & 0,73 & & 0,93 & 0,89 & 0,92 & 0,74 & 0,94 & 0,87 \\
\hline
\end{tabular}

$\mathrm{tFe}_{2} \mathrm{O}_{3}$, toplam demir oksit; LOI, Ateşte Kayıp
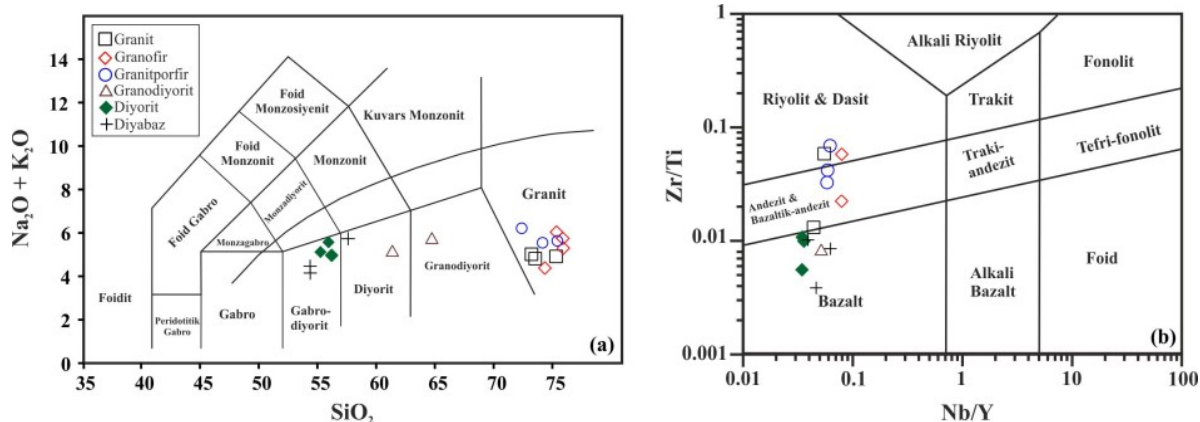

Şekil 6. Magmatik komplekse ait kayaçların a) toplam alkali ve $\mathrm{SiO}_{2}$ diyagramındaki konumları [27], b) $\mathrm{Nb} / \mathrm{Y}-\mathrm{Zr} / \mathrm{Ti}$ diyagramındaki konumları [28]. Alkali-subalkali ayrımı çizgisi Miyashiro [29] 

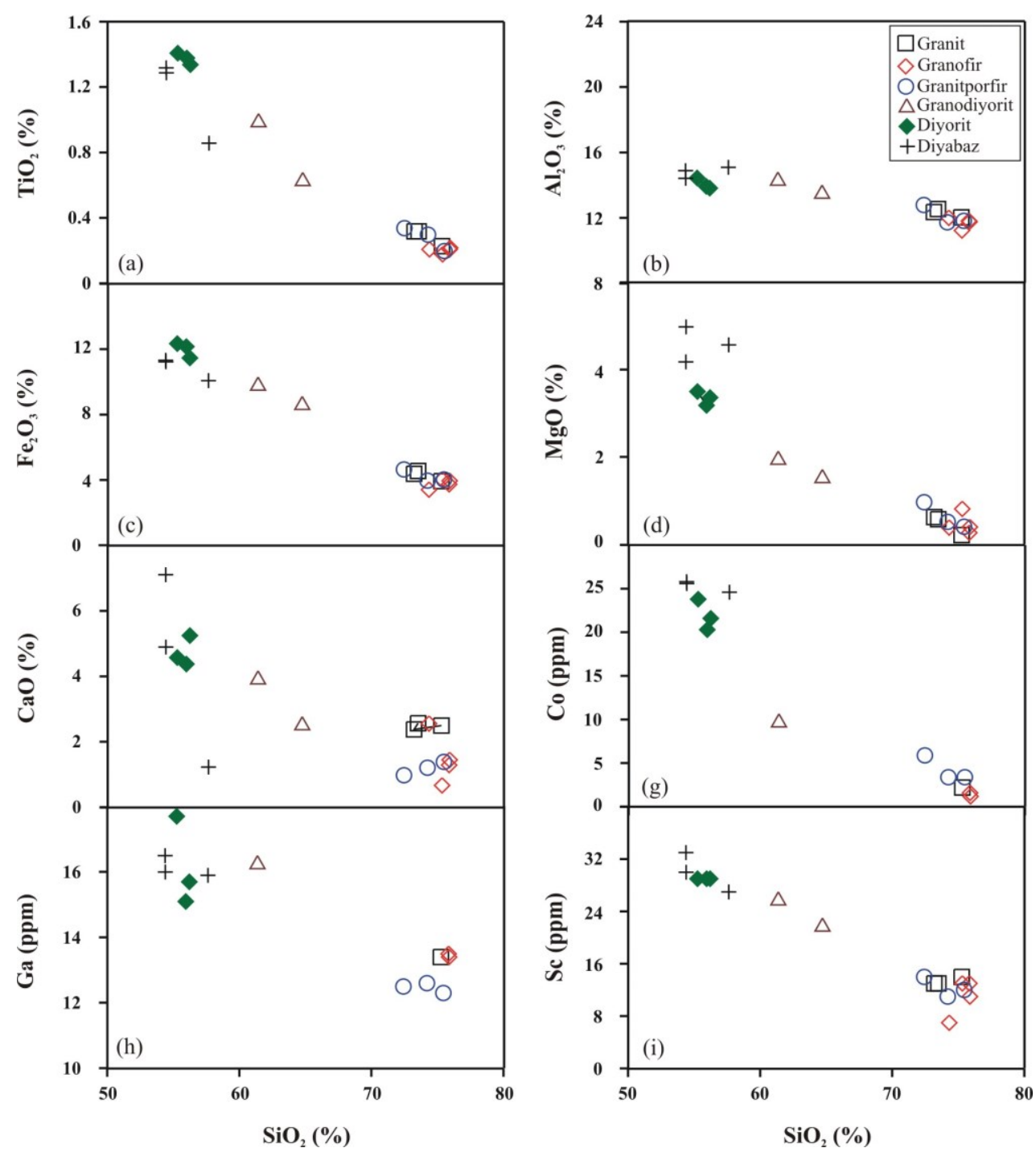

Şekil 7. Magmatik komplekse ait kayaçların ana ve iz element içeriklerinin $\mathrm{SiO}_{2}$ 'e karşı değişimleri

Granitik kayaçların okyanus ortası sırtı granitlerine (ORG) göre normalize edilmiş örümcek diyagramı (Şekil 9a) incelendiğinde yüksek iyon yarıçaplı elementlerden sadece $\mathrm{Ba}$ elementinde bir zenginleşme gözlenirken, kalıcıllğı yüksek elementlerce ( $\mathrm{Ta}, \mathrm{Nb}, \mathrm{Hf}, \mathrm{Zr}, \mathrm{Sm}, \mathrm{Y}, \mathrm{Yb}$ ) ise genel bir tüketilme izlenmektedir. Granit porfir örneklerinde $\mathrm{K}_{2} \mathrm{O}, \mathrm{Rb}$ ve $\mathrm{Ba}$ elementlerinin diğer kayaç örneklerine göre daha fazla tüketilme göstermesi alterasyonun diğer kayaçlara göre daha fazla olduğunu göstermektedir. Çamlıyayla yöresindeki magmatik komplekse ait granitik kayaçlar bu özellikleri ile Umman yay granitlerine benzerlik göstermektedirler (Şekil 9a). Diyorit ve diyabaz kayaçlarının okyanus ortası sırt bazaltlarına (MORB) göre normalize edilmiş örümcek diyagramında ise örnekler yüksek iyon yarıçaplı elementlerce zenginleşme, kalıcılı $\breve{g}_{1}$ yüksek elementlerce tüketilme sunmaktadırlar (Şekil 9b). Diyorit ve diyabaz kayaçlarında gözlenen negatif $\mathrm{Nb}$ anomalisi bu kayaçların oluşumunda yitim bileşeninin varlığını işaret etmektedir [30,31]. 


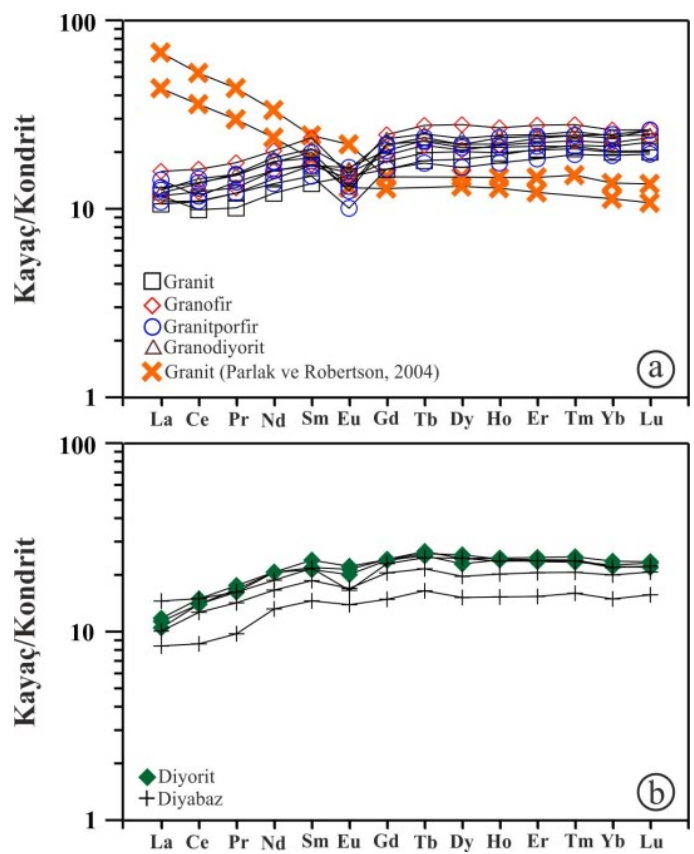

Şekil 8. Magmatik komplekse ait kayaçların nadir toprak element diyagramı. Kondrit değerleri [32]'den alınmıştır
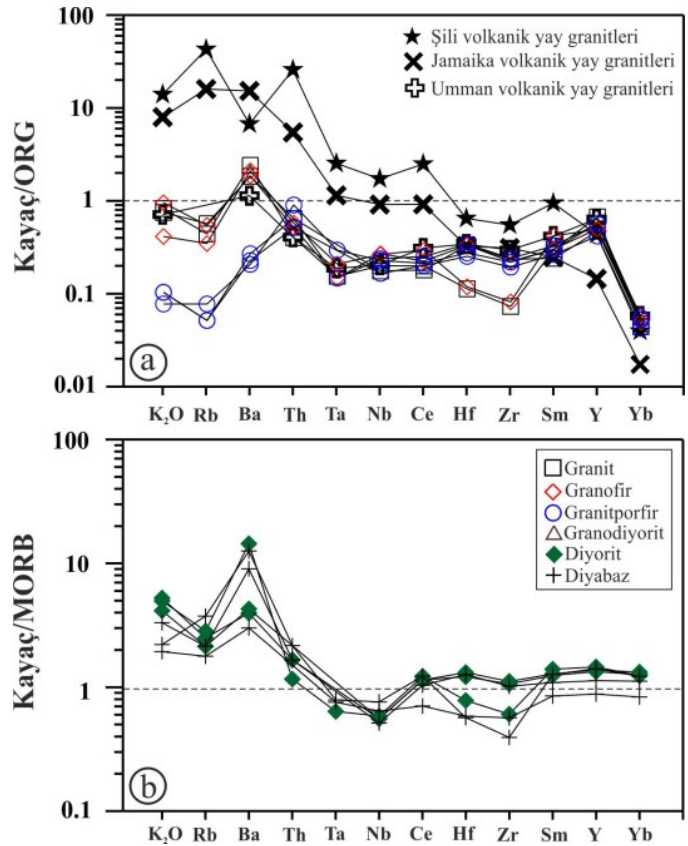

Şekil 9. Magmatik komplekse ait kayaçların örümcek diyagramı ORG, Şili, Jamaika, Umman volkanik yay granitleri değerleri [33] ve MORB değerleri [32]'den alınmıştır 
Granitik kayaçların tektonomagmatik ortam ayırım diyagramlarından $\mathrm{Nb}-\mathrm{Y}$ [33] diyagramında (Şekil 10a) volkanik yay granitleri (VAG) ile çarpışmayla eşyaşlı granitleri (Syn-COLG) alanına düştükleri düştükleri gözlenmektedir. Örneklerin Okyanus sırtı granitlerin (ORG) sınırına yakın olmas1 magmatizma sonras1 metamorfizma, alterasyon ve tektonik etkilerden kaynaklanmaktadır [30]. Harris ve arkadaşları [34] Hf-Rb-Ta üçgen diyagramında (Şekil 10b) iki adet örnek (granit ve granofir) plaka içi alanlarında izlenirken diğer örnekler volkanik yay alanında gözlenmektedir. Ta-Nb [34] diyagramında (Şekil 10c) ise oldukça düşük $\mathrm{Nb}$ ve Ta içerikleri ile örnekler volkanik yay alanında yer almaktadır. Diyorit ve diyabaz daykları için kullanılan $\mathrm{Ti} / 1000-\mathrm{V}$ [35] tektonomagmatik ortam ayırım diyagramında (Şekil 10d) bir adet diyabaz örneği IAT-MORB sınırında, diğer diyabaz ve diyorit örnekleri okyanus ortası sirt bazaltları ile yay gerisi baseni bazaltları alanlarında yer almaktadır.
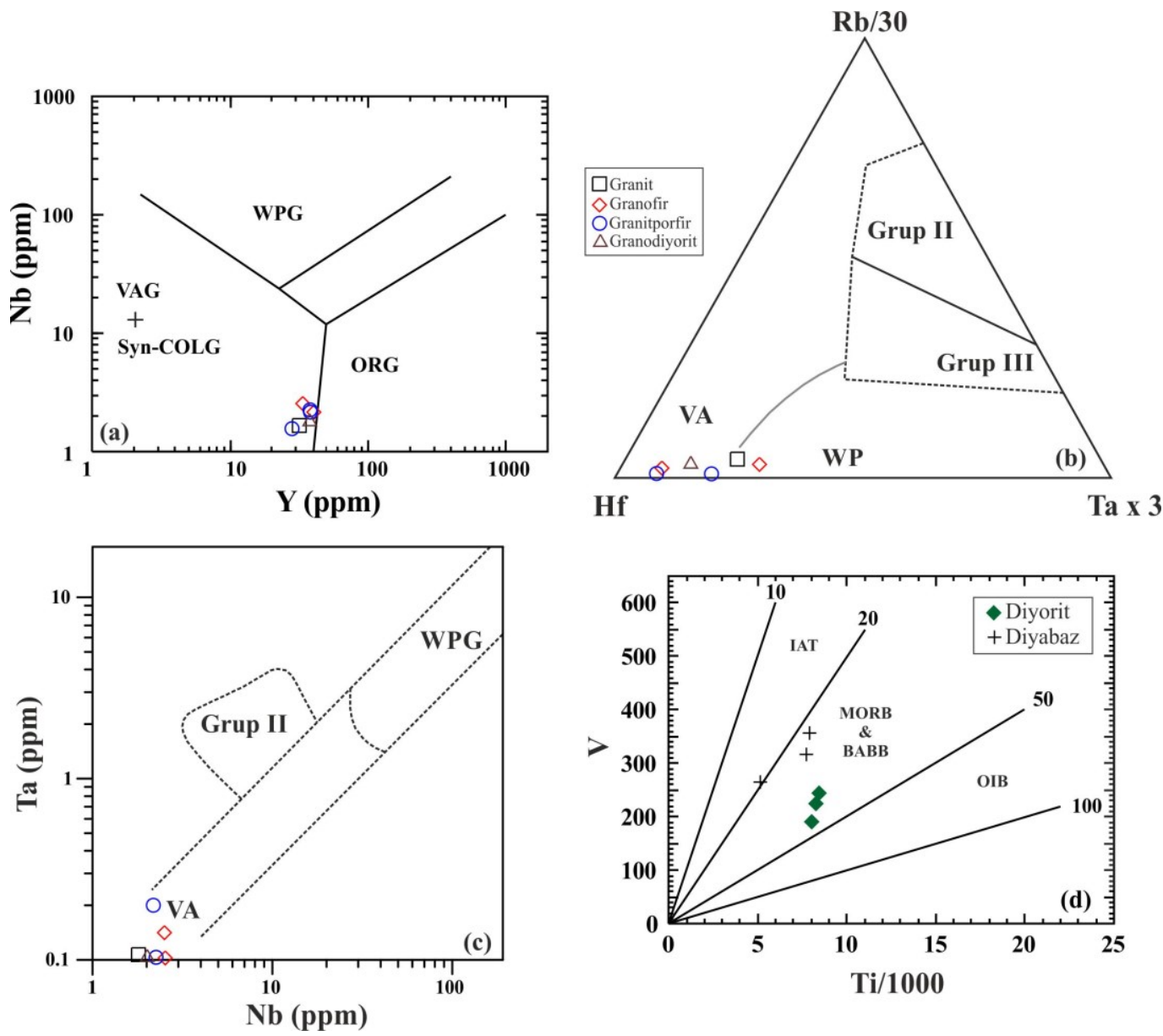

Şekil 10. Magmatik kaya kompleksine ait kayaçların (a) Nb-Y [33]; (b) Hf-Rb-Ta [34]; (c) Nb-Ta [34]; (d) Ti/1000-V [35] tektonomagmatik ortam ayrım diyagramlarındaki konumları. VAG/VA: Volkanik yay granitleri; WPG/WP: Levha içi granitleri; Syn-COLG (Grup II): Çarpışmayla eşyaşlı granitler; Grup III: Çarpışma sonrası granitleri;ORG: Okyanus sırtı granitleri. IAT: Ada yayı toleyiti; MORB: Okyanus ortası sırt bazaltlar1; BABB: Yay-gerisi baseni bazaltlar1; OIB: Okyanus adası bazaltları. toleyiti; MORB: Okyanus ortası sirt bazaltlar1; BABB: Yay-gerisi baseni bazaltları; OIB: Okyanus adası bazaltları 


\section{TARTIŞMA VE SONUÇLAR}

Toros orojenik kuşağının Geç Kretase'deki evriminde, ofiyolitler ve ofiyolitik melanj birimleri ile ilişkili tektonomagmatik/stratigrafik birimler önemli yer tutmaktadır. Çalışma alanının içinde bulunduğu Anatorid-Torid kuşağı boyunca, inceleme alanının yaklaşık $40 \mathrm{~km}$ batısında ofiyolitik melanj içerisinde blok olarak Geç Devoniyen granitik kütlelerin [17], Afyon zonunda Karbonifer yaşlı granitlerin [36] ve Orta Anadolu bölgesinde Geç Kretase yaşlı granitik kütlelerin (Üçkapı graniti) [37] varlığı bilinmektedir. Ayrıca, ofiyolit yerleşiminden sonra bölgedeki magmatizma faaliyetleri Eosen yaşlı Horoz graniti [38] ile temsil edilmektedir.

Çamlıyayla (Mersin) güneyinde yüzeyleyen magmatik kompklesin dokanağının Mersin ofiyoliti ile faylı olmasından dolayı kesme ilişkisi net bir şekilde gözlenememektedir. Birim ayrıca Oligosen-Miyosen yaşı ıirimler tarafından açısal uyumsuzlukla üzerlenmektedir. $\mathrm{Bu}$ çalışmada, magmatik kayaların oldukça altere olması, dokanak ilişkilerinin belirli olmaması, yaşının belirlenememesinden dolayı oluşum yaşı ve tektonik ortamı önceki çalışmalara dayanarak $[17,36]$ melanj içerisinde blok olarak değerlendirilmiştir.

Jeokimyasal olarak örneklerin ana-iz element içerikleri, nadir toprak element diyagramlarındaki benzerlik köken olarak aynı magma ürünleri olabileceğini göstermektedir. Granitik kayaçların okyanus sırt granitlerine göre normalize edilmiş örümcek diyagramı ve tektonik ortam ayırım diyagramları bu kayaçların volkanik yay granitleri ile ilgili benzerlik sunduğunu, diyoritik ve diyabaz kayaçlarında gözlenen negatif $\mathrm{Nb}$ anomalisi ve yatay dağılım ise yay ile ilişkili olduklarını göstermektedir.

Arazi, petrografik ve jeokimyasal çalışmalar sonucunda aşağıdaki sonuçlar bulunmuştur.

1. Magmatik kaya kompleksi Mersin melanj1 içerisinde blok olarak gözlenmekte. granit, granodiyorit, granofir, granit porfir, diyorit ve diyabaz gibi derinlik ve yarı derinlik kayaçlarından oluşmaktadır.

2. Komplekse ait kayaçlar subalkali karakterde olup, REE içerikleri LREE'ce çok az bir tüketilme göstermektedir.

3. Granitlerin örümcek diyagramında iz elementlerin ORG'a göre tüketildiği izlenirken, diyorit ve diyabaz daykların MORB'a göre normalize edilmiş örümcek diyagramları LILE elementlerince zenginleşme ve negatif $\mathrm{Nb}$ anomalisi sunmaktadır.

4. Tektonomagmatik sinıflanma diyagramları bu kayaçların yay ile ilişkili tektonik ortamlarda oluştuğuna işaret etmektedir.

\section{TEŞEKKÜR}

Bu çalışma Mersin Üniversitesi Bilimsel Araştırma Projeler Birimi tarafından BAP-MÜH F JM (UB) 2009-9 numaralı proje kapsaminda desteklenmiştir.

\section{KAYNAKLAR}

1. Özgül, N., 1976. Torosların Bazı Temel Jeolojik Özellikleri. Türkiye Jeoloji Kurumu Bülteni, 19, 65-79.

2. Özgül, N., 1984. Stratigraphy and Tectonic Evolution of the Central Taurides. In: O. Tekeli and M.C. Göncüoğlu (eds.), Geology of the Taurus Belt, International Symposium, 77-99.

3. Demirtaşl1, E., 1984. Stratigraphy and Tectonics of the area between Silifke and Anamur, Central Taurus Mountains. In: O. Tekeli and M.C. Göncüoğlu (eds.), Geology of the Taurus Belt, International Symposium, 101-118.

4. Demirtaşlı, E., Turhan, N., Bilgin, A.Z., Selim, M., 1984. Geology of the Bolkar Mountains. In: O. Tekeli and M.C. Göncüoğlu (eds.), Geology of the Taurus Belt, International Symposium, 125-141.

5. Gül, M.A., Çuhadar, Ö., Özbaş, Y., Alkan, H., Efeçınar, T., 1984. Bolkar-Belemedik 
Yöresinin Jeolojisi ve Petrol Olanakları. TPAO Raporu, No: 1972, 159, (yayımlanmamış).

6. Akay, E., Uysal, Ş., 1988. Orta Toroslar'ın Post-Eosen Tektoniği. M.T.A. Dergisi, 108, 57-68.

7. Öztürk, E.M., Öcal, H., Taşkıran, A., Bulduk, A., Çelik, B., Metin, T., Keskin, Ö., Kadir, S., Değer, Z., Çatal, E., Keskin, A., Gökten, A., Hakyemez, A., Girgin, İ., 1991. Orta Toroslar'1n Jeolojisi. M.T.A. Raporu, No:9301, Ankara, 138.

8. Özgül, N., 1997. Bozkır-Hadim-Taşkent (Orta Toroslar'in Kuzey Kesimi) Dolayında Yer Alan Tektono-Stratigrafik Birliklerin Stratigrafisi. M.T.A. Dergisi, 119, 113-174.

9. Alan, İ., Şahin, Ş., Keskin, H., Altun, İ., Bakırhan, B., Balcı, V., Saçlı, L., Pehlivan, Ş., Kop, A., Hanilçi, N., Çelik, Ö.F., 2007. Orta Toroslar'ın Jeodinamik Evrimi, Ereğli (Konya) -Ulukışla (Niğde)-Karsantı (Adana)-Namrun (Mersin) Yöresi. MTA Raporu, No:11006, Ankara (Yayınlanmamış), 245.

10. Keniş, Ü., 1988. Sarıkavak (Tarsus-İçel) Manyezit yataklarının jeolojisi ve metallojenezi. Ç.Ü. Fen Bilimleri Enstitüsü, Yüksek Lisans Tezi, 58.

11. Türkmen, S., 1994. Pamukluk Barajının (Tarsus) Mühendislik Jeolojisi İncelemesi. Ç.Ü. Fen Bilimleri Enstitüsü, Doktora Tezi, 2004.

12. Türkmen, S., İşler, F., 1995. Pamukluk Barajı Yerindeki (Tarsus) Mağmatik Kaya Kompleksinin Petrografik ve Mühendislik Özellikleri. Yerbilimleri, 26, 153-166.

13. Açlan, M., İşler, F., 1996. Namrun Güneydoğusu (Mersin) Yöresinin Jeolojik ve Petrografik İncelemesi. Yerbilimleri, 28, 179-187.

14. Tekbaş, M., 2000. Namrun Güneyi (ÇaparParmakkurdu) Arası Ofiyolit Diliminin Jeolojisi ve Petrografik İncelemesi. Ç.Ü. Fen Bilimleri Enstitüsü, Yüksek Lisans Tezi, 66.

15. Gök, M., 2006. Çamlıyayla (Tarsus Kuzeyi) Güney Kesiminin Jeolojisi. Ç.Ü. Fen Bilimleri Enstitüsü, Yüksek Lisans Tezi, 51.

16. Parlak, O., 1996. Geochemistry and Geochronology of the Mersin Ophiolite within the Eastern Mediterranean Tectonic Frame (Southern Turkey). These Doctorat,
Universitede Geneve, Terre \& Environnement 6, 242.

17. Parlak, O., Robertson, A.H.F., 2004. The Ophiolite-Related Mersin Melange, Southern Turkey: Its Role in the Tectonic- Sedimentary Setting of Tethys in the Eastern Mediterranean Region. Geological Magazine, 141(3), 257-286.

18. Koç, H., Taslı, K., 2010. Stratigraphy and Paleoenvironmental Development of the Late Cretaceous Deposits in the Central Taurides (S Turkey). $7^{\text {st }}$ International symposium on Eastern Mediterranean Geology, Abstract Book, 153, Adana, Türkiye.

19. Koç, H., Tasl1, K., Özer, E., 2015. Bolkar Dağlar1 (Orta Toroslar) Güneyindeki Maastrihtiyen İstiflerinin Stratigrafisi ve Fasiyesleri, G Türkiye. 16. PaleontolojiStratigrafi Çalıştayı, Bildiri Özleri, 44-45, Rize, Türkiye.

20. Pampal, S., 1984. Arslanköy-Tepeköy (Mersin) Yöresinin Jeolojisi. S.Ü. Fen-Edebiyat Fakültesi, Fen Dergisi, Sayı: 3.

21. Özer, E., Koç, H., Özsayar, T.Y., 2004. Stratigraphical Evidence for The Depression of The Northern Margin of The MenderesTauride Block (Turkey) During The Late Cretaceous. Journal of Asian Earth Sciences, 22, 401-412.

22. Parlak, O., Bozkurt, E., Delaloye, M., 1996. The Obduction Direction of the Mersin Ophiolite: Structural Evidence from Subophiolitic Metamorphics in the Central Tauride Belt, Southern Turkey. International Geology Review, 38, 778-786.

23. Avşar, N., 1992. Namrun Yöresinin Bentik Foraminifer Faunas1. MTA Dergisi, 114, 127144.

24. Başalan, A., İnan, N., Koç, H., Taslı, K., İnan, S., 2007. Geology of the Southernpart of Çamliyayla (NE Mersin) and Contributions on Description of the Güzeller Formation. Yerbilimleri-Geosound, 50-51, 115-137.

25. Yetiş, C., Demirkol, C., 1986. Adana Baseni Batı Kesiminin Detay Jeolojik Etüdü. MTA Raporu, Rapor No:8037-8037a, 187, (yayımlanmamış). 
26. Whitney, D.L., Evans, B.W., 2010 Abbreviations for Names of Rock-forming Minerals. Am. Miner., 95, 185-187.

27. Middlemost, E. A. K., 1994, Naming Materials in Magma/igneous Rock System: Earth Science Reviews, 37, 215-224.

28. Pearce, J.A., 1996. A user's Guide to Basalt Discrimination Diagrams, in Wyman, D.A. (ed.), Trace Element Geochemistry of Volcanic Rocks: Applications for Massive Sulphide Exploration: Geological Association of Canada, Short Course Notes, 12, 79-113.

29. Miyashiro, A., 1978. Nature of Alkalic Volcanic Rock Series: Contributions to Mineralogy and Petrology, 66, 91-104.

30. Pearce, J.A., 1983. Role of the Subcontinental Lithosphere in Magma Genesis at Active Continental Margins. In: C.J. Hawkesworth And M.J. Norry (eds.), Continental Basalts and Mantle Xenoliths, Shiva Publishing, Cheshire, 230-249.

31. Wilson, M., 1989. Igneous Petrogenesis: a Global Tectonic Approach. Chapman and Hall, London, 1-466.

32. Sun, S.S., Mcdonough, W.F., 1989. Chemical and Isotopic Systematics of Ocean Basalts: Implications for Mantle Composition and Processes. In: A.D, Saunders and M.J. Norry (eds.), Magmatism in the Ocean Basins, Geological Society of London Special Publication, 42, 313-46.

33. Pearce, J.A., Harris, N.B.W., Tidle, A.G., 1984. Trace Element Discrimination Diagram For The Tectonic Interpretation of Granitic Rocks. Journ of Petrol, 25, 956-983.

34. Harris, N.B.W., Pearce, J.A., Tindle, A.G. 1986. Geochemical Characteristics of Collision-Zone Magmatism. In: Coward, M.P. \& Ries, A.C. (eds) Collision Tectonics. Geological Society, London, Special Publication, 19, 67-81.

35. Shervais, J.W., 1982. Ti-V Plots and the Petrogenesis of Modern Ophiolitic Lavas. Earth and Planetary Science Letters 59, 101-118.

36. Candan, O., Akal, C., Koralay, E.O., Okay, A.I., Oberhansli, R., Prelevic, D., Mertz-Kraus, R., 2016. Carboniferous Granites on the Northern Magrin of Gondwana, Anatolide-
Tauride Block, Turkey-evidence for South Ward Subduction of Paleotethys. Tectonophysics, 683, 349-366.

37. Göncüoğlu, M.C., 1986. Orta Anadolu Masifinin Güney Ucundan Jeokronolojik Yaş Bulgular1. MTA Derg. 105/106, 111-124.

38. Kadığlu, Y.K., Dilek, Y., 2010. Structure and Geochemistry of the Adakitic Horoz Granitoid, Bolkar Mountains, South-central Turkey, and its Tectonomagmatic Evolution. International Geology Review, 52, 505-535. 
